\title{
Runx2 expression: A mesenchymal stem marker for cancer
}

\author{
MARIA TERESA VALENTI ${ }^{1,2}$, PAOLA SERAFINI ${ }^{1,2}$, GIULIO INNAMORATI $^{2,3}$, ANNA GILI $^{2}$, \\ SAMUELE CHERI ${ }^{2}$, CLAUDIO BASSI ${ }^{3}$ and LUCA DALLE CARBONARE ${ }^{1,2}$ \\ ${ }^{1}$ Department of Medicine, Section of Internal Medicine D; ${ }^{2}$ University Laboratory of Medical Research; \\ ${ }^{3}$ Department of Surgery, Section of General Surgery B, University of Verona, I-37134 Verona, Italy
}

Received July 1, 2015; Accepted August 9, 2016

DOI: $10.3892 / \mathrm{ol} .2016 .5182$

\begin{abstract}
The transcription factor runt-related transcription factor 2 (Runx2) is a master gene implicated in the osteogenic differentiation of mesenchymal stem cells, and thus serves a determinant function in bone remodelling and skeletal integrity. Various signalling pathways regulate Runx2 abundance, which requires a number of molecules to finely modulate its expression. Furthermore, this gene may be ectopically-expressed in cancer cells. Recent studies have reported the involvement of Runx 2 in cell proliferation, epithelial-mesenchymal transition, apoptosis and metastatic processes, suggesting it may represent a useful therapeutic target in cancer treatment. However, studies evaluating this gene as a cancer marker are lacking. In the present study, Runx 2 expression was analysed in 11 different cancer cell lines not derived from bone tumour. In addition, the presence of Runx2-related cell-free RNA was examined in the peripheral blood of 41 patients affected by different forms of tumours. The results demonstrated high expression levels of Runx 2 in the cancer cell lines and identified the presence of Runx2-related cell-free RNA in the peripheral blood of patients with cancer. As compared with normal individuals, the expression level was increased by 14.2-fold in patients with bone metastases and by 4.01 -fold in patients without metastases. The results of the present study therefore opens up the possibility to exploit Runx 2 expression as a cancer biomarker allowing the use of minimally invasive approaches for diagnosis and follow-up.
\end{abstract}

\section{Introduction}

The osteogenic differentiation process of mesenchymal stem cells involves either systemic hormones or specific local molecules, including transforming growth factor- $\beta 1 / 2$ (TGF- $\beta$ ), fibroblast growth factor-2 (FGF-2), bone morphogenic

Correspondence to: Dr Maria Teresa Valenti, Department of Medicine, Section of Internal Medicine D, University of Verona, Piazzale Scuro 10, I-37134 Verona, Italy

E-mail: mariateresa.valenti@univr.it

Key words: epithelial-mesenchymal transition, cancer, Runx2, gene expression, cell-free RNA proteins (BMPs), insulin-like growth factor (IGF), prostaglandins, vascular endothelial growth factors (VEGFs) and the Wnt/ $\beta$-catenin pathway (1). As a result, intracellular signalling promotes the expression of transcription factors. Among these, runt-related transcription factor 2 (Runx2) serves a pivotal role and it is considered a master gene for osteogenic differentiation (1). Runx 2 induces the expression of specific downstream genes, including collagen type I, bone alkaline phosphatase, osteopontin and osteocalcin (2), and it is essential for terminal chondrocyte differentiation (3). Runx 2 knock-out mice are affected by cleidocranial dysplasia syndrome (3), while Runx 2 overexpression in mice impairs mineralization, suggesting that this gene affects bone formation in different ways (4). A previous study demonstrated that the expression of Runx 2 in circulating mesenchymal stem cells was lower in patients with osteoporosis when compared with normal donors (5). Runx 2 expression is modulated by several regulatory pathways. Important negative regulators include histone deacetylases (HDACs), in particular HDAC3, HDAC4, HDAC5, HDAC6 and HDAC7 (6). Twist proteins (7), activator protein 1 , transcription factor 4 and osterix are additional regulators of Runx 2 expression (2). Furthermore, it has been demonstrated that Runx2 function may be downmodulated by microRNA (miR) action, in particular miR-3960 (8), and phosphorylation induced by the extracellular signal-regulated kinase/mitogen-activated protein kinase pathway results in Runx 2 activation (9). The involvement of Runx 2 in the oncogenic process has been recently suggested to occur in human osteosarcoma (10), in addition to other forms of malignancy such as pancreatic and thyroid cancer, and increased expression correlates with a poor prognosis $(11,12)$.

Epithelial-mesenchymal transition (EMT) is involved in carcinogenesis and promotes metastatic spreading (13-15). Following its recognition as a regulator gene in transformed epithelial cells in breast, lung and thyroid carcinoma (13-15), it has been suggested that Runx 2 may promote breast cancer metastasis by EMT (13). The cancer caused by EMT is a consequence of complicated reprogramming process involving differentiation, epigenetics and metabolic balance disruption (16). In this scenario, Runx 2 has been identified as a regulator gene of transformed epithelial cells in breast, lung and thyroid carcinoma (13-15), and it has been suggested that this gene promotes breast cancer metastasis via EMT (13).

A number of researchers have focused on identifying cancer markers that may provide clinical information a less 
invasive way. A previous study reported that Runx 2 expression was elevated in the tissue, serum and circulating cells of patients with thyroid cancer suggesting that Runx 2 may serve as a useful biomarker for thyroid malignancies (17).

On the basis of these findings, the present study speculated that Runx 2 may be expressed in cells derived from malignancies other than bone tumours. Therefore, the expression of this gene was analysed in pancreatic, melanoma, breast and prostate cancer cell lines. In addition, in order to evaluate potential applications in oncological malignancies, Runx2 cell-free RNA was examined in sera obtained from patients affected by various forms of cancer.

\section{Materials and methods}

Cell culture. A total of 4 pancreatic, 2 breast, 3 prostate and 2 bone human cancer cell lines, purchased by American Type Culture Collection (Rockville, MD, USA), were used in the present study (Table I). Table I specified the previous applications of these cell lines studies (18-28). The pancreatic cancer cell lines were cultured in RPMI 1640 (Sigma-Aldrich; Merck Millipore, Darmstadt, Germany) with $10 \%$ foetal bovine serum (FBS) (Sigma-Aldrich; Merck Millipore), whereas the breast, prostate and bone cell lines were cultured as previously described (29-33). For cell synchronization, cell cycles were arrested at $G_{1}$ phase by adding $400 \mathrm{mM}$ mimosine (Sigma-Aldrich; Merck Millipore) for $24 \mathrm{~h}$ as previously described (34). Cells subsequently underwent three washes with PBS (Sigma-Aldrich; Merck Millipore) and were cultured in serum-free RPMI 1640 medium for 3 days. Finally, cells were cultured in fresh RPMI 1640 medium with 10\% FBS (plus 2 mM L-glutamine and penicillin/streptomycin) until they reached $70 \%$ confluence. Adherent cells and supernatants for each cell line were harvested to perform expression analyses. For each cell line, three different cultures were tested.

Patients. Characteristics of the population analysed are presented in Table II. A total of 41 patients with cancer were positively diagnosed from 2010 to 2013 by pathologists (Pancreas Institute; Integrated University Hospital of Verona, Verona, Italy) prior to providing blood samples, and 41 age-matched donors, who were hospitalized in Clinic of Internal Medicine, Integrated University Hospital of Verona for cardiovascular or metabolic diseases, were recruited as controls. Bone metastases were present in 17 patients. All subjects had provided written informed consent and the study was approved by the local Institutional Ethics Committee of the Integrated University Hospital of Verona.

Serum preparation. Serum samples were obtained following three rounds of centrifugation $(800 \times g, 1,000 \times g$ and $1,500 \times g$ at $4^{\circ} \mathrm{C}$ ) of collected blood to keep lymphocyte contamination to a minimum as previously described (35).

RNA extraction and reverse transcription. RNA from cancer cell lines was extracted using the RNeasy ${ }^{\circledR}$ Mini kit (Qiagen, Hilden, Germany), and RNA extraction from sera and culture supernatants was performed using the QIAamp ${ }^{\circledR}$ UltraSens ${ }^{\circledR}$ Virus kit (Qiagen) with DNAse I treatment according to the manufacturer's protocol. First-strand cDNA was generated using the High-Capacity cDNA Archive kit with random hexamers (Applied Biosystems; Thermo Fisher Scientific, Inc., Waltham, MA, USA) according to the manufacturer's protocol. cDNA products were stored at $-80^{\circ} \mathrm{C}$ until use.

Quantitative polymerase chain reaction ( $q P C R)$. PCR was performed in a total volume of $50 \mu \mathrm{l}$ containing $1 \mathrm{X}$ Taqman Universal PCR Master mix, No AmpErase ${ }^{\circledR}$ UNG and $5 \mu 1$ cDNA. The real time amplifications included $10 \mathrm{~min}$ at $95^{\circ} \mathrm{C}$, followed by 40 cycles at $95^{\circ} \mathrm{C}$ for $15 \mathrm{sec}$ and at $60^{\circ} \mathrm{C}$ for $1 \mathrm{~min}$. Predesigned, gene-specific primers and a probe set for Runx2 were obtained from Assay-on-Demand ${ }^{\mathrm{TM}}$ Gene Expression products (Applied Biosystems; Thermo Fisher Scientific, Inc.). In order to normalize the results, the following three housekeeping genes were used: $\beta$-actin (structural gene), glyceraldehyde 3-phosphate dehydrogenase (GAPDH; metabolism-related gene) and $\beta-2$ microglobulin (component of major histocompatibility complex class I gene). The primer sequences were pre-designed by the supplier (Applied Biosystems; Thermo Fisher Scientific, Inc.). The relative expression levels of the Runx 2 gene were calculated for each sample following normalization using the $2-^{\Delta \Delta \mathrm{Ct}}$ method for comparing differences in relative fold expression (36). The data are reported as mRNA fold expression.

Western blot analysis. Cells were lysed on ice for $45 \mathrm{~min}$ in a buffer containing protease inhibitor cocktail [1\% IGEPAL $^{\circledR}$, $1 \%$ sodium dodecyl sulfate (SDS), $10 \%$ glycerol, $1 \mathrm{mM}$ ethylenediaminetetraacetic acid, 5\% b-mercaptoethanol, $1.5 \%$ Triton X-100 and 4\% Protease Inhibitor Cocktail (Sigma-Aldrich; Merck Millipore)]. Cell lysates were then centrifuged $(10,000 \mathrm{x} \mathrm{g})$ for $15 \mathrm{~min}$ at $4^{\circ} \mathrm{C}$ to remove insoluble materials. Protein concentration in the supernatants was measured using the Coomassie Protein assay kit (Pierce Biotechnology, Inc., Rockford, IL, USA). Proteins (70 $\mu \mathrm{g}$ ) were separated by $10 \%$ SDS-polyacrylamide gel electrophoresis and electrotransferred onto a polyvinylidene fluoride membrane. The membrane was subsequently blocked for 30 min with 3\% bovine serum albumin (Sigma-Aldrich; Merck Millipore) in $0.05 \%$ Tween 20 with Tris-buffered saline (t-TBS) at room temperature. For immunodetection, blots were incubated for $2 \mathrm{~h}$ at room temperature on titer plate agitator with anti-Runx2 antibodies (cat no. 05-1478; dilution 1:500; clone AS110; EMD Millipore, Billerica, MA, USA). The membranes were washed three times in t-TBS, incubated at room temperature with horseradish peroxidase-conjugated anti-rabbit secondary antibodies (dilution, 1:2,500) in TBS for $1 \mathrm{~h}$ and washed in fresh t-TBS three times for a total of 20 min. Bands were detected using Luminata ${ }^{\mathrm{TM}}$ Forte Western HRP Substrate (Merck Millipore) and a G:BOX Chemi XX6 (Syngene, Frederick, MD, USA).

Statistical analysis. Results are expressed as the mean \pm standard error. The Wilcoxon signed-ranked test was used for non-parametric data. Analysis of variance followed by Bonferroni correction was performed as a post-hoc analysis and the results are expressed as the mean \pm standard error of the mean. $\mathrm{P}<0.05$ was considered to indicate a statistically significant difference. Analyses were applied to experiments 
Table I. Cancer cell lines.

\begin{tabular}{|c|c|c|c|c|}
\hline Author, year & Cell line & Source & Tumour & Refs. \\
\hline Morgan et al, 1980 & Colo357 & Metastatic & Pancreatic & $(18)$ \\
\hline Kim et al, 1989 & HPAF & Metastatic & Pancreatic & (19) \\
\hline Lieber et al, 1975 & Panc1 & Primary & Pancreatic & (20) \\
\hline Parekh et al, 1994 & BON & Metastatic & Pancreatic & $(21)$ \\
\hline Soule et al, 1973 & $\mathrm{~T} 47 \mathrm{D}$ & Metastatic & Breast & $(22)$ \\
\hline Keydar et al, 1979 & MCF7 & Metastatic & Breast & $(23)$ \\
\hline Stone et al, 1978 & DU145 & Metastatic & Prostatic & (24) \\
\hline Tai et al, 2011 & PC3 & Primary & Prostatic & $(25)$ \\
\hline Horoszewicz et al, 1983 & LNCaP & Metastatic & Prostatic & (26) \\
\hline Niforou et al, 2008 & $\mathrm{U} 2 \mathrm{OS}$ & Primary & Osteosarcoma & (27) \\
\hline Billiau et al, 1977 & MG63 & Primary & Osteosarcoma & (28) \\
\hline
\end{tabular}

A

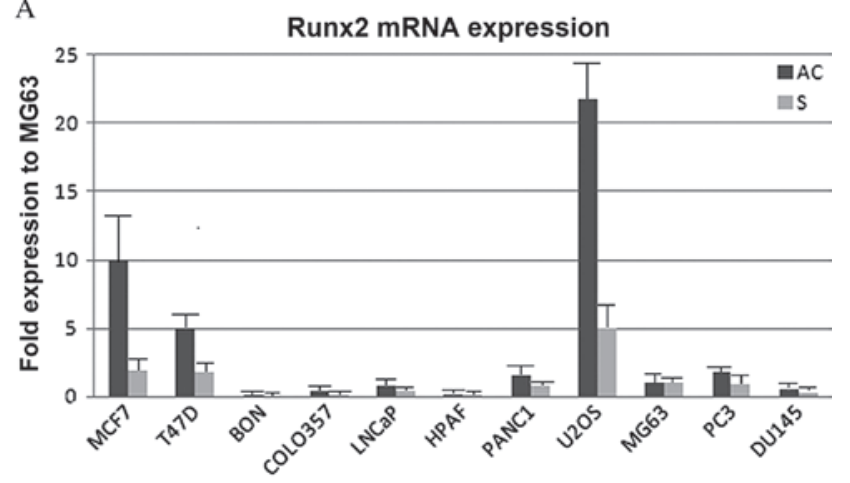

B

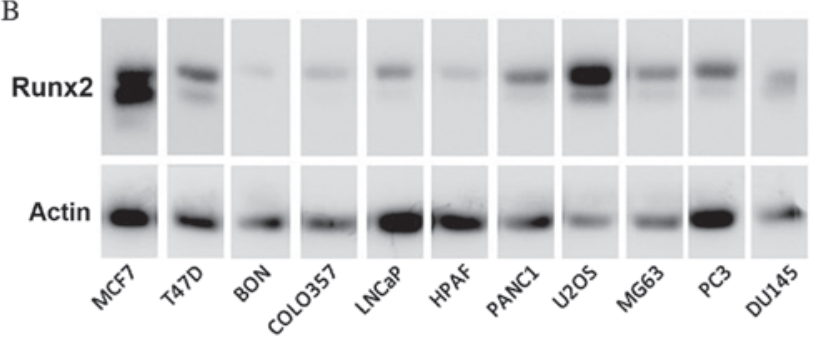

Figure 1. Runx2 mRNA fold expression in ACs and Ss of cancer cell lines. (A) All cell lines expressed Runx2 mRNA and (B) immunoblotting demonstrated that the ACs also expressed Runx2 protein. Runx2, runt-related transcription factor 2; ACs, adherent cells; Ss, supernatants.

carried out at least three times, and statistical analyses were performed using SPSS v16.0 (SPSS, Inc., Chicago, IL, USA).

\section{Results}

Runx2 expression in cancer cell lines. Runx2 gene expression was analysed in adherent cells and in culture supernatants, and the MG63 cell line was used as a calibrator (fold of expression). It was observed that Runx 2 mRNA was expressed in adherent cells and supernatants of the cancer cell lines, although expression was largely varied across the different cell types (Fig. 1A). In order to analyse the expression of Runx 2 protein in adherent cells, immunoblotting using anti-Runx 2 antibodies was performed. The results demonstrated that the protein was also expressed in all cell lines (Fig. 1B).
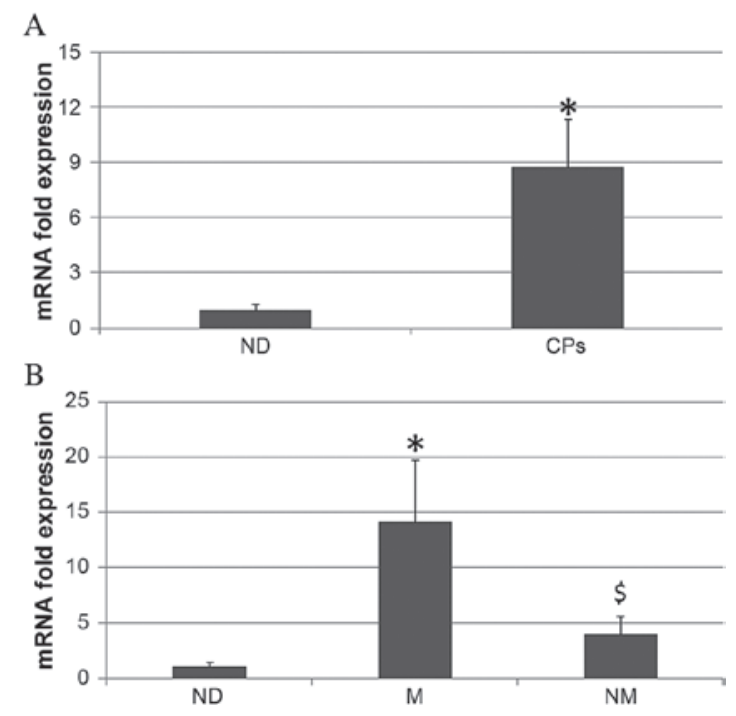

Figure 2. Runx2 expression in patients with cancer. (A) Circulating Runx2 mRNA in CPs was higher than in NDs $\left({ }^{*} \mathrm{P}<0.01\right)$, and (B) patients with $\mathrm{M}$ expressed higher levels of Runx2 ("P<0.01) than NM patients with respect to NDs $\left({ }^{\$} \mathrm{P}<0.05\right)$. Runx2, runt-related transcription factor 2 ; $\mathrm{CP}$, cancer patients; NDs, normal donors; M, bone metastases; NM, non-metastatic.

Runx 2 gene expression in patients with cancer. The expression data of patients with cancer was reported as fold of expression in respect to a calibrator (40 normal donors). Patients with cancer and normal donors each expressed Runx 2 mRNA; however, their expression levels were different. Notably, the expression of Runx 2 in the patients with cancer was 8.74 ( \pm 3.5 )-fold higher than the normal donors ( $\mathrm{P}<0.01$; Fig. $2 \mathrm{~A})$. In addition, Runx 2 mRNA expression in patients with bone metastases was higher than in patients without metastases. Runx 2 expression in patients with metastases was 14.12 ( \pm 4.2$)$-fold higher than the normal donors $(\mathrm{P}<0.01)$, whereas in patients without metastases Runx2 expression was 4.01 ( \pm 2.01$)$-fold higher than the normal donors $(\mathrm{P}<0.05)$ (Fig. 2B).

\section{Discussion}

In order to establish less invasive methods for the diagnosis and follow-up of patients with cancer, research has aimed 
Table II. Characteristics of the study population.

\begin{tabular}{|c|c|c|c|c|}
\hline $\mathrm{N}$ & Gender & Age, years & Diagnosis & TNM \\
\hline 1 & M & 65 & Neuroendocrine adenocarcinoma & TxN1M1 \\
\hline 2 & M & 80 & Intestinal adenocarcinoma & T1-2N0M0 \\
\hline 3 & $\mathrm{M}$ & 71 & Hepatocarcinoma & T3N1M0 \\
\hline 4 & M & 55 & Prostatic adenocarcinoma & T2N0M0 \\
\hline 5 & M & 83 & Prostatic adenocarcinoma & T3N0M1 \\
\hline 6 & M & 87 & Prostatic adenocarcinoma & T4N1M0 \\
\hline 7 & $\mathrm{M}$ & 66 & Prostatic adenocarcinoma & T2N0M0 \\
\hline 8 & $\mathrm{M}$ & 67 & Kidney adenocarcinoma & T4N0M0 \\
\hline 9 & $\mathrm{M}$ & 73 & Intestinal adenocarcinoma & TxN0M0 \\
\hline 10 & M & 94 & Gastric adenocarcinoma & T3N0M0 \\
\hline 11 & M & 81 & Gastric adenocarcinoma & T3N2M0 \\
\hline 12 & M & 70 & Lung carcinoma & T1N1M1 \\
\hline 13 & $\mathrm{M}$ & 70 & Mesenchymal cancer & T4NxM1 \\
\hline 14 & $\mathrm{M}$ & 81 & Prostatic adenocarcinoma & T1N1M1 \\
\hline 15 & M & 92 & Breast carcinoma & $\mathrm{T} 2 \mathrm{~N} 1 \mathrm{M} 1$ \\
\hline 16 & $\mathrm{M}$ & 60 & Intestinal adenocarcinoma & T1-2N0M0 \\
\hline 17 & $\mathrm{M}$ & 75 & Pancreatic adenocarcinoma & T3N1M1 \\
\hline 18 & $\mathrm{M}$ & 60 & Pancreatic adenocarcinoma & T3N1M1 \\
\hline 19 & $\mathrm{M}$ & 64 & Pancreatic adenocarcinoma & T3N0M0 \\
\hline 20 & $\mathrm{M}$ & 67 & Pancreatic adenocarcinoma & T1N0M0 \\
\hline 21 & M & 78 & Bladder carcinoma & T1N0M0 \\
\hline 22 & $\mathrm{~F}$ & 87 & Hepatocarcinoma & T3N0M0 \\
\hline 23 & $\mathrm{~F}$ & 72 & Intestinal adenocarcinoma & T1N0M0 \\
\hline 24 & F & 27 & Adrenal carcinoma & T3-4N1M1 \\
\hline 25 & $\mathrm{~F}$ & 82 & Intestinal adenocarcinoma & TxN0M0 \\
\hline 26 & $\mathrm{~F}$ & 82 & Lung carcinoma & T2N0M0 \\
\hline 27 & $\mathrm{~F}$ & 52 & Esophageal carcinoma & T4N1M1 \\
\hline 28 & $\mathrm{~F}$ & 68 & Ovarian carcinoma & T3N2M1 \\
\hline 29 & $\mathrm{~F}$ & 80 & Breast carcinoma & $\mathrm{T} 2 \mathrm{~N} 1 \mathrm{M} 1$ \\
\hline 30 & $\mathrm{~F}$ & 86 & Breast carcinoma & T0N1M1 \\
\hline 31 & $\mathrm{~F}$ & 75 & Lung carcinoma & T1NxM0 \\
\hline 32 & $\mathrm{~F}$ & 81 & Pancreatic adenocarcinoma & T3N0M0 \\
\hline 33 & $\mathrm{~F}$ & 71 & Bladder carcinoma & T3aN1M0 \\
\hline 34 & $\mathrm{~F}$ & 62 & Pancreatic adenocarcinoma & T3N1M1 \\
\hline 35 & $\mathrm{~F}$ & 71 & Pancreatic adenocarcinoma & T4N0M0 \\
\hline 36 & $\mathrm{~F}$ & 75 & Pancreatic adenocarcinoma & T3N0M0 \\
\hline 37 & $\mathrm{~F}$ & 70 & Pancreatic adenocarcinoma & T1N0M0 \\
\hline 38 & $\mathrm{~F}$ & 49 & Pancreatic adenocarcinoma & T1N0M0 \\
\hline 39 & $\mathrm{M}$ & 78 & Prostatic adenocarcinoma & T2N0M1 \\
\hline 40 & M & 80 & Prostatic adenocarcinoma & T2N0M1 \\
\hline 41 & $\mathrm{M}$ & 75 & Prostatic adenocarcinoma & T3N1M1 \\
\hline
\end{tabular}

TNM, tumour-node-metastasis.

to identify cell-free RNA encoding for genes upregulated in cancer malignancies $(17,35,37)$. Previous studies primarily focused on osteosarcoma and metastatic breast and prostate cancer have linked Runx2 to neoplastic transformation (38-41). The present study enrolled patients affected by various types of tumours, including pancreatic, prostatic, intestinal, lung, breast, gastric, liver, neuroendocrine, kidney, mesenchymal, adrenal gland, oesophageal and ovarian cancer. Notably, the results of the current study demonstrated an increase in Runx2 circulating mRNA in multiple forms of cancer, thus opening the possibility to investigate it as a relatively comprehensive biomarker.

The Runx gene family is comprised of three related transcription factors, which are involved in the differentiation 
of multiple haematopoietic lineages (Runx1), cartilage and bone (Runx2) and epithelial tissues (Runx3). However, all three genes are implicated in cancer by promoting (Runx1 and Runx2) or suppressing (Runx3) neoplastic transformation (42). Multiple mechanisms contribute to Runx2 functional modulation, including post-translational modification, in addition to protein-protein interaction and direct stimulation (11). Several hypotheses, such as the involvement of integrin alpha5 (39), p53 (43) or microRNA-205 (40) have been put forward to describe the molecular process of Runx 2 in carcinogenesis. In osteosarcoma, loss of p53 upregulates Runx 2 expression (43); this cause-effect relationship may explain Runx 2 ectopic expression in various forms of cancer.

P53 and Runx2 have been demonstrated to be part of the regulatory network controlling EMT (44). P53 controls miRNAs, major EMT-related signalling pathways (TGF- $\beta$, Wnt, IGF, and signal transducer and activator of transcription), and EMT-associated transcription factors that promote a chemoresistant phenotype, invasion and loss of cell polarity (44). The direct involvement of Runx 2 in cancer was demonstrated by downmodulation experiments in thyroid carcinoma cells (15) and upregulation experiments in breast cancer (45). EMT represents an early event of tumour progression and is mediated by well-characterized transcription factors (e.g. Snail and Twist family and helix-loop-helix factors) (46). The present study speculates that Runx2 participates in these events to promote invasion and metastasis in a larger number of cancer forms than previously anticipated. The data from the current study demonstrated an increase in the concentration of circulating cell-free Runx 2 cell-free mRNA in patients with metastasis. In agreement with these results, Runx 2 has been repeatedly identified as a regulator of bone metastases in breast and prostate cancer in previous studies (47-49). Bone is particularly recurrent as a target of metastasizing cells, thus a master skeletal transcription factor like Runx 2 may be extremely relevant in potentiating tumour cell invasiveness of bone marrow, among others, contributing directly to the osteolysis process (38). Further studies with a larger number of patients should be performed in order to validate the predictive value of minimally invasive tests based on Runx 2 cell-free mRNA.

In conclusion, the present study demonstrated that Runx2 is expressed at high levels in osteosarcoma and expanded this finding to non-osseous cells, thus supporting the possible use of Runx2-related cell-free RNA as a cancer marker for screening purposes. In addition, this useful, less invasive method may allow clinicians to monitor the development of metastases in patients with cancer.

\section{References}

1. Dalle Carbonare L, Innamorati G and Valenti MT: Transcription factor Runx 2 and its application to bone tissue engineering. Stem Cell Rev 8: 891-897, 2012.

2. Cohen MM Jr: Perspectives on RUNX genes: An update. Am J Med Genet A 149A: 2629-2646, 2009.

3. Otto F, Thornell AP, Crompton T, Denzel A, Gilmour KC, Rosewell IR, Stamp GW, Beddington RS, Mundlos S, Olsen BR, et al: Cbfa1, a candidate gene for cleidocranial dysplasia syndrome, is essential for osteoblast differentiation and bone development. Cell 89: 765-771, 1997.

4. Otto F, Lübbert M and Stock M: Upstream and downstream targets of RUNX proteins. J Cell Biochem 89: 9-18, 2003.
5. Valenti MT, Garbin U, Pasini A, Zanatta M, Stranieri C Manfro S, Zucal C and Dalle Carbonare L: Role of ox-PAPCs in the differentiation of mesenchymal stem cells (MSCs) and Runx 2 and PPAR $\gamma 2$ expression in MSCs-like of osteoporotic patients. PloS One 6: e20363, 2011.

6. Jensen ED, Schroeder TM, Bailey J, Gopalakrishnan R and Westendorf JJ: Histone deacetylase 7 associates with Runx 2 and represses its activity during osteoblast maturation in a deacetylation-independent manner. J Bone Miner Res 23: 361-372, 2008.

7. Yousfi M, Lasmoles F and Marie PJ: TWIST inactivation reduces CBFA1/RUNX2 expression and DNA binding to the osteocalcin promoter in osteoblasts. Biochem Biophys Res Commun 297: 641-644, 2002.

8. Hu R, Liu W, Li H, Yang L, Chen C, Xia ZY, Guo LJ, Xie H, Zhou HD, Wu XP and Luo XH: A Runx2/miR-3960/miR-2861 regulatory feedback loop during mouse osteoblast differentiation. J Biol Chem 286: 12328-12339, 2011.

9. Ge C, Xiao G, Jiang D, Yang Q, Hatch NE, Roca H and Franceschi RT: Identification and functional characterization of ERK/MAPK phosphorylation sites in the Runx2 transcription factor. J Biol Chem 284: 32533-32543, 2009.

10. Lau CC, Harris CP, Lu XY, Perlaky L, Gogineni S, Chintagumpala M, Hicks J, Johnson ME, Davino NA, Huvos AG, et al: Frequent amplification and rearrangement of chromosomal bands 6p12-p21 and 17p11.2 in osteosarcoma. Genes Chromosomes Cancer 39: 11-21, 2004.

11. Kayed H, Jiang X, Keleg S, Jesnowski R, Giese T, Berger MR, Esposito I, Löhr M, Friess H and Kleeff J: Regulation and functional role of the Runt-related transcription factor- 2 in pancreatic cancer. Br J Cancer 97: 1106-1115, 2007.

12. Endo T, Ohta K and Kobayashi T: Expression and function of Cbfa-1/Runx2 in thyroid papillary carcinoma cells. J Clin Endocrinol Metab 93: 2409-2412, 2008.

13. Owens TW, Rogers RL, Best SA, Ledger A, Mooney AM, Ferguson A, Shore P, Swarbrick A, Ormandy CJ, Simpson PT, et al: Runx2 is a novel regulator of mammary epithelial cell fate in development and breast cancer. Cancer Res 74: 5277-5286, 2014.

14. Hsu YL, Huang MS, Yang CJ, Hung JY, Wu LY and Kuo PL: Lung tumor-associated osteoblast-derived bone morphogenetic protein-2 increased epithelial-to-mesenchymal transition of cancer by Runx2/Snail signaling pathway. J Biol Chem 286: 37335-37346, 2011.

15. Niu DF, Kondo T, Nakazawa T, Oishi N, Kawasaki T, Mochizuki K, Yamane T and Katoh R: Transcription factor Runx2 is a regulator of epithelial-mesenchymal transition and invasion in thyroid carcinomas. Lab Invest 92: 1181-1190, 2012.

16. $\mathrm{Li} \mathrm{L}$ and Li W: Epithelial-mesenchymal transition in human cancer: Comprehensive reprogramming of metabolism, epigenetics, and differentiation. Pharmacol Ther 150: 33-46, 2015.

17. Dalle Carbonare L, Frigo A, Francia G, Davì MV, Donatelli L, Stranieri C, Brazzarola P, Zatelli MC, Menestrina F and Valenti MT: Runx2 mRNA expression in the tissue, serum, and circulating non-hematopoietic cells of patients with thyroid cancer. J Clin Endocrinol Metab 97: E1249-E1256, 2012.

18. Morgan RT, Woods LK, Moore GE, Quinn LA, McGavran L and Gordon SG: Human cell line (COLO 357) of metastatic pancreatic adenocarcinoma. Int J Cancer 25: 591-598, 1980.

19. Kim YW, Kern HF, Mullins TD, Koriwchak MJ and Metzgar RS: Characterization of clones of a human pancreatic adenocarcinoma cell line representing different stages of differentiation. Pancreas 4: 353-362, 1989.

20. Lieber M, Mazzetta J, Nelson-Rees W, Kaplan M and Todaro G: Establishment of a continuous tumor-cell line (panc-1) from a human carcinoma of the exocrine pancreas. Int J Cancer 15: 741-747, 1975.

21. Parekh D, Ishizuka J, Townsend CM Jr, Haber B, Beauchamp RD, Karp G, Kim SW, Rajaraman S, Greeley G Jr and Thompson JC: Characterization of a human pancreatic carcinoid in vitro: Morphology, amine and peptide storage, and secretion. Pancreas 9: 83-90, 1994.

22. Soule HD, Vazguez J, Long A, Albert S and Brennan M: A human cell line from a pleural effusion derived from a breast carcinoma. J Natl Cancer Inst 51: 1409-1416, 1973.

23. Keydar I, Chen L, Karby S, Weiss FR, Delarea J, Radu M, Chaitcik S and Brenner HJ: Establishment and characterization of a cell line of human breast carcinoma origin. Eur J Cancer 15: 659-670, 1979.

24. Stone KR, Mickey DD, Wunderli H, Mickey GH and Paulson DF: Isolation of a human prostate carcinoma cell line (DU 145). Int J Cancer 21: 274-281, 1978. 
25. Tai S, Sun Y, Squires JM, Zhang H, Oh WK, Liang CZ and Huang J: PC3 is a cell line characteristic of prostatic small cell carcinoma. Prostate 71: 1668-1679, 2011.

26. Horoszewicz JS, Leong SS, Kawinski E, Karr JP, Rosenthal H, Chu TM, Mirand EA and Murphy GP: LNCaP model of human prostatic carcinoma. Cancer Res 43: 1809-1818, 1983.

27. Niforou KM, Anagnostopoulos AK, Vougas K, Kittas C, Gorgoulis VG and Tsangaris GT: The proteome profile of the human osteosarcoma U2OS cell line. Cancer Genomics Proteomics 5: 63-78, 2008

28. Billiau A, Edy VG, Heremans H, Van Damme J, Desmyter J, Georgiades JA and De Somer P: Human interferon: Mass production in a newly established cell line, MG-63. Antimicrob Agents Chemother 12: 11-15, 1977.

29. Dalle Carbonare L, Valenti MT, Bertoldo F, Fracalossi A, Balducci E, Azzarello G, Vinante O and Lo Cascio V: Amino-bisphosphonates decrease hTERT gene expression in breast cancer in vitro. Aging Clin Exp Res 19: 91-96, 2007.

30. Valenti MT, Dalle Carbonare L, Bertoldo F, Donatelli L and Lo Cascio V: The effects on hTERT gene expression is an additional mechanism of amino-bisphosphonates in prostatic cancer cells. Eur J Pharmacol 580: 36-42, 2008.

31. Gatta V, Drago D, Fincati K, Valenti MT, Dalle Carbonare L, Sensi SL and Zatta P: Microarray analysis on human neuroblastoma cells exposed to aluminum, $\beta(1-42)$-amyloid or the beta (1-42)-amyloid aluminum complex. PloS One 6: e15965, 2011.

32. Murayama T, Kawasoe Y, Yamashita Y, Ueno Y, Minami S, Yokouchi M and Komiya S: Efficacy of the third-generation bisphosphonate risedronate alone and in combination with anticancer drugs against osteosarcoma cell lines. Anticancer Res 28: 2147-2154, 2008

33. Valenti MT, Zanatta M, Donatelli L, Viviano G, Cavallini C, Scupoli MT and Dalle Carbonare L: Ascorbic acid induces either differentiation or apoptosis in MG-63 osteosarcoma lineage. Anticancer Res 34: 1617-1627, 2014.

34. Galindo M, Pratap J, Young DW, Hovhannisyan H, Im HJ, Choi JY, Lian JB, Stein JL, Stein GS and van Wijnen AJ: The bone-specific expression of Runx 2 oscillates during the cell cycle to support a G1-related antiproliferative function in osteoblasts. J Biol Chem 280: 20274-20285, 2005.

35. Valenti MT, Dalle Carbonare L, Donatelli L, Bertoldo F, Giovanazzi B, Caliari F and Lo Cascio V: STEAP mRNA detection in serum of patients with solid tumours. Cancer Lett 273: 122-126, 2009.

36. Livak KJ and Schmittgen TD: Analysis of relative gene expression data using real-time quantitative PCR and the 2(-Delta Delta C (T)) method. Methods 25: 402-408, 2001.
37. Dalle Carbonare L, Gasparetto A, Donatelli L, Dellantonio A and Valenti MT: Telomerase mRNA detection in serum of patients with prostate cancer. Urol Oncol 31: 205-210, 2013.

38. Pratap J, Lian JB and Stein GS: Metastatic bone disease: Role of transcription factors and future targets. Bone 48: 30-36, 2011

39. Li XQ, Lu JT, Tan CC, Wang QS and Feng YM: RUNX2 promotes breast cancer bone metastasis by increasing integrin a5-mediated colonization. Cancer Lett 380: 78-86, 2016.

40. Zhang C, Long F, Wan J, Hu Y and He H: MicroRNA-205 acts as a tumor suppressor in osteosarcoma via targeting RUNX2. Oncol Rep 35: 3275-3284, 2016.

41. Ge C, Zhao G, Li Y, Li H, Zhao X, Pannone G, Bufo P, Santoro A, Sanguedolce F, Tortorella S, et al: Role of Runx2 phosphorylation in prostate cancer and association with metastatic disease. Oncogene 35: 366-376, 2016.

42. Blyth K, Vaillant F, Jenkins A, McDonald L, Pringle MA, Huser C, Stein T, Neil J and Cameron ER: Runx2 in normal tissues and cancer cells: A developing story. Blood Cells Mol Dis 45: 117-123, 2010

43. He Y, de Castro LF, Shin MH, Dubois W, Yang HH, Jiang S, Mishra PJ, Ren L, Gou H, Lal A, et al: p53 loss increases the osteogenic differentiation of bone marrow stromal cells. Stem Cells 33: 1304-1319, 2015.

44. Engelmann D and Pützer BM: Emerging from the shade of p53 mutants: N-terminally truncated variants of the p53 family in EMT signaling and cancer progression. Sci Signal 7: re9, 2014.

45. Chimge NO, Baniwal SK, Little GH, Chen YB, Kahn M, Tripathy D, Borok Z and Frenkel B: Regulation of breast cancer metastasis by Runx 2 and estrogen signaling: The role of SNAI2. Breast Cancer Res 13: R127, 2011.

46. Lee JY and Kong G: Roles and epigenetic regulation of epithelial-mesenchymal transition and its transcription factors in cancer initiation and progression. Cell Mol Life Sci: Jul 26, 2016 (Epub ahead of print)

47. Akech J, Wixted JJ, Bedard K, van der Deen M, Hussain S, Guise TA, van Wijnen AJ, Stein JL, Languino LR, Altieri DC, et al: Runx2 association with progression of prostate cancer in patients: Mechanisms mediating bone osteolysis and osteoblastic metastatic lesions. Oncogene 29: 811-821, 2010

48. Leong DT, Lim J, Goh X, Pratap J, Pereira BP, Kwok HS Nathan SS, Dobson JR, Lian JB, Ito Y, et al: Cancer-related ectopic expression of the bone-related transcription factor RUNX2 in non-osseous metastatic tumor cells is linked to cell proliferation and motility. Breast Cancer Res 12: R89, 2010.

49. Baniwal SK, Khalid O, Gabet Y, Shah RR, Purcell DJ, Mav D, Kohn-Gabet AE, Shi Y, Coetzee GA and Frenkel B: Runx2 transcriptome of prostate cancer cells: Insights into invasiveness and bone metastasis. Mol Cancer 9: 258, 2010. 